\title{
Influence of some tablets on corrosion resistance of orthodontic wire made of SS 316L alloy in artificial saliva
}

\author{
A. Anandan, ${ }^{1} *$ S. Rajendran, ${ }^{2,3}$ J. Sathiyabama ${ }^{3}$ and D. Sathiyaraj ${ }^{1}$ \\ ${ }^{I}$ SKV Higher Secondary School, Kandampalayam-637201, India \\ ${ }^{2}$ Corrosion Research Centre, Department of Chemistry, St Antony's College of Arts and \\ Sciences for Women, Dindigul-624005 \\ ${ }^{3} P G$ and Research Department of Chemistry, GTN Arts College, Dindigul-624005, \\ Tamil Nadu, India \\ E-mail: susairajendran@gmail.com
}

\begin{abstract}
Corrosion resistance of orthodontic wire made of SS 316L alloy in artificial saliva in the absence and presence of five tablets namely, Limcee-500mg, Shelcal-500mg, Ferikind, Cefixime-200mg, Biogenetic (Aluminium Hydroxide And Magnesium Trisilicate), has been evaluated by polarisation study and $\mathrm{AC}$ impedence spectra. It is observed that in the presence of the tablets Ferikind and Biogenetic (Aluminium Hydroxide and Magnesium Trisilicate) the corrosion resistance of SS 316L alloy increases. On the other hand in the presence of the tablets Limcee- 500mg, Shelcal-500mg and Cefixime-200mg the corrosion resistance of SS 316L alloy decreases. Hence it is recommended that people implanted with orthodontic wires made of SS 316L alloy need not hesitate to take the tablets Ferikind and Biogenetic (Aluminium Hydroxide and Magnesium Trisilicate) orally. People having implanted with orthodontic wire made of SS 316L should avoid taking tablets Limcee$500 \mathrm{mg}$, Shelcal-500mg and Cefixime-200mg. The increase in corrosion resistance or decrease in corrosion resistance of SS 316L alloy in the presence of these tablets in artificial saliva is due to the ingredients present in tablets.
\end{abstract}

Keywords: orthodontic wires, artificial saliva, tablets, corrosion resistance, polarisation study and AC impedence spectra.

Received: December 30, 2016. Published: March 23, 2017.

doi: $\underline{10.17675 / 2305-6894-2017-6-2-3}$

\section{Introduction}

Orthodontic wires made of various metals and alloys have been used to control the growth of teeth. These wires may undergo corrosion because they are in contact with saliva. Moreover corrosion may be caused by the food items and tablets taken orally by the people. Many research activities are going on in this field throughout the world. The tribo corrosion of titanium in artificial saliva in the presence of benzotriazole has been studied [1]. The corrosion behaviour of nickel-cobalt alloy in artificial saliva has been 
investigated [2]. Kinani and Chtaini have investigated the influence of eugenol on the corrosion resistance of titanium in artificial saliva [3].

Zeiebowicz et al. have studied the corrosion behaviour of commercial orthodontic wires in the oral environment [4]. Liu et al. has investigated the corrosion resistance of nickel-chromium alloy in artificial saliva [5]. The corrosion resistance of palladium-silver alloy [6], dental amalgam [7, 8] titanium alloy [9] in artificial saliva has been investigated. Rajendran et al. have studied the influence of spirulina [10] D-glucose [11] and electoral [12] on varies metal and alloy in artificial saliva.

The present work is undertaken to investigate the influence of five tablets namely (B) - Limcee-500mg, (C) - Shelcal-500 mg, (D) - Ferikind, (E) - Cefixime-200mg, and (F) - Biogenetic (Aluminium Hydroxide And Magnesium Trisilicate) on the corrosion resistance of SS 316L alloy in the presence of artificial saliva. Tablets Limcee $500 \mathrm{mg}$ and Ferikind are used to generate auto immune system and prevent dental plaque and scurvy. Shelcal $500 \mathrm{mg}$ is used for the growth of strong teeth and to prevent dental cavities. Cefixime $200 \mathrm{mg}$ is used to protect infection disease caused by dental cavities. Biogenetic is used to avoid stomach disorder caused by use of excessive intake of drug. Electrochemical studies such as polarisation study and AC impedance spectra have been employed to investigate the corrosion resistance of the orthodontic wires.

\section{Experimental}

\section{Preparation of Artificial saliva solution}

Artificial saliva is prepared in laboratory and the composition of artificial saliva is as follows:

$\mathrm{KCl}-0.4 \mathrm{~g} / \mathrm{lit}, \mathrm{NaCl}-0.4 \mathrm{~g} / \mathrm{lit}, \mathrm{CaCl}_{2} .2 \mathrm{H}_{2} \mathrm{O}-0.906 \mathrm{~g} / \mathrm{lit}, \mathrm{NaH}_{2} \mathrm{PO}_{4} .2 \mathrm{H}_{2} \mathrm{O}-0.690 \mathrm{~g} / \mathrm{lit}$, $\mathrm{Na}_{2} \mathrm{~S} \cdot 9 \mathrm{H}_{2} \mathrm{O}-0.005 \mathrm{~g} /$ lit, Urea $-1 \mathrm{~g} /$ lit.

Table 1. Composition of five tablets.

\begin{tabular}{ccc}
\hline Tablet names & Composition & Represented by \\
\hline $\begin{array}{c}\text { Limcee-500mg } \\
\text { (Vitamin-C Chewable })\end{array}$ & $\begin{array}{c}\text { 1. Ascorbic acid }-100 \mathrm{mg} \\
\text { 2. Sodium Ascorbate }-450 \mathrm{mg}\end{array}$ & Tablet-B \\
\hline $\begin{array}{c}\text { Shelcal-500mg } \\
\text { (Calcium with Vitamin- } \\
\text { D3) }\end{array}$ & $\begin{array}{c}\text { 1. Calcium carbonate from an organic } \\
\text { source (power oyster shell) }-1250 \mathrm{mg} \\
\text { 2. Vitamin D3 }-259 \mathrm{Iu}\end{array}$ & Tablet-C \\
\hline $\begin{array}{c}\text { Ferikind } \\
\text { (Ascorbic Acid) }\end{array}$ & $\begin{array}{c}\text { 1. Ferikind Elemental iron } 100 \mathrm{mg} \\
\text { 2. Folic acid } 1.5 \mathrm{mg}\end{array}$ & Tablet-D \\
\hline Cefixime-200mg & Cefixime as unhydrate $-200 \mathrm{mg}$ & Tablet-E \\
\hline $\begin{array}{c}\text { Biogenetic (Aluminium } \\
\text { Hydroxide And } \\
\text { Magnesium Trisilicate) }\end{array}$ & $\begin{array}{c}\text { 1. Magnesium trisilicate }-250 \mathrm{mg} \\
\text { 2. Dried aluminium hydroxide gel }-120 \mathrm{mg} \\
\text { 3. Peppermint oil }-0.003 \mathrm{ml}\end{array}$ & Tablet-F \\
\hline
\end{tabular}




\section{Electrochemical studies}

The corrosion resistance of SS 316L alloy has been measured by electrochemical studies such as Polarisation study and AC impedance spectra. A CHI electrochemical work station with impedance model 660A was used for this purpose. A three electrode cell assembly (Figure 1) was used in the present study. SS 316L alloy was used as working electrode; saturated calomel electrode was used as reference electrode and Platinum electrode was used as counter electrode. From the Polarisation study corrosion parameters such as corrosion potential, corrosion current and Tafel slope values were calculated. The AC impedance spectra charge transfer resistance and double layer capacitance values were calculated.

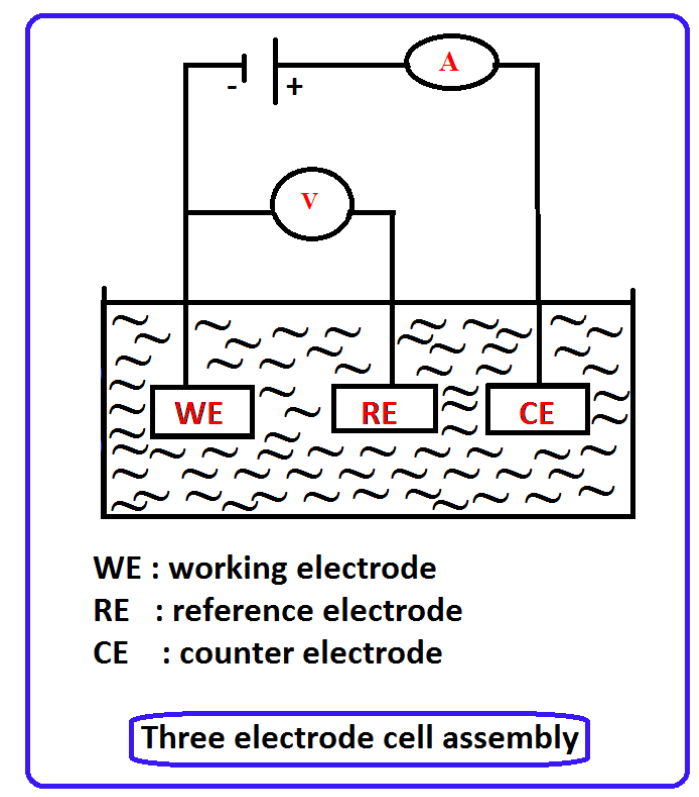

Figure 1. Three electrode cell assembly.

\section{Results and Discussion}

\section{Analysis of Potentiodynamic Polarisation curves}

The corrosion resistance of SS 316L alloy in artificial saliva in the absence and presence of five tablets have been evaluated by polarisation study [13-16]. The corrosion parameters, namely, corrosion potential $\left(E_{\text {corr }}\right)$, Tafel slopes (cathodic $=b_{\mathrm{c}}$ and anodic $=b_{\mathrm{a}}$ ), linear polarization resistance (LPR) and corrosion current $\left(I_{\text {corr }}\right)$ values have been derived from the polarisation study. The scan rate $(\mathrm{V} / \mathrm{s})$ was 0.01 . Hold time at $\left(E_{\mathrm{fcs}}\right)$ was zero and quiet time (s) was 2. The resulting parameters are summarized in Table 2. The polarisation curves are shown in Figure 2. The Linear Polarisation Resistance values of SS 316L in artificial saliva in the absence and presence of five tablets are compared graphically in Figure 3. 
Table 2. Corrosion parameters of SS 316L alloy immersed in Artificial Saliva (AS) in the absence and presence of five tablets obtained from polarization study.

\begin{tabular}{|c|c|c|c|c|c|}
\hline System & $\begin{array}{c}\text { LPR } \\
\text { Ohm cm } \text { cm }^{2}\end{array}$ & $\begin{array}{c}I_{\text {corr }} \\
\mathbf{A} / \mathbf{c m}^{2}\end{array}$ & $\begin{array}{c}E_{\text {corr }} \\
\mathrm{mVV} v \mathrm{~s} \text { SCE }\end{array}$ & $\begin{array}{c}b_{\mathbf{c}} \\
\mathrm{mV} / \text { decade }\end{array}$ & $\begin{array}{c}b_{\mathrm{a}} \\
\mathrm{mV} / \text { decade }\end{array}$ \\
\hline AS & 1614129 & $2.843 \times 10^{-8}$ & -598 & 179 & 256 \\
\hline $\begin{array}{c}\text { AS + Tablet B } \\
(300 \mathrm{ppm})\end{array}$ & 646635 & $6.796 \times 10^{-8}$ & -678 & 165 & 259 \\
\hline $\begin{array}{c}\text { AS + Tablet C } \\
(300 \mathrm{ppm})\end{array}$ & 1117464 & $4.054 \times 10^{-8}$ & -628 & 186 & 236 \\
\hline $\begin{array}{l}\text { AS + Tablet D } \\
(300 \mathrm{ppm})\end{array}$ & 13331084 & $0.344 \times 10^{-8}$ & -436 & 189 & 238 \\
\hline $\begin{array}{c}\text { AS + Tablet E } \\
(300 \mathrm{ppm})\end{array}$ & 634458 & $7.884 \times 10^{-8}$ & -642 & 170 & 354 \\
\hline $\begin{array}{c}\text { AS + Tablet F } \\
(300 \mathrm{ppm})\end{array}$ & 1831029 & $2.532 \times 10^{-8}$ & -605 & 198 & 230 \\
\hline
\end{tabular}

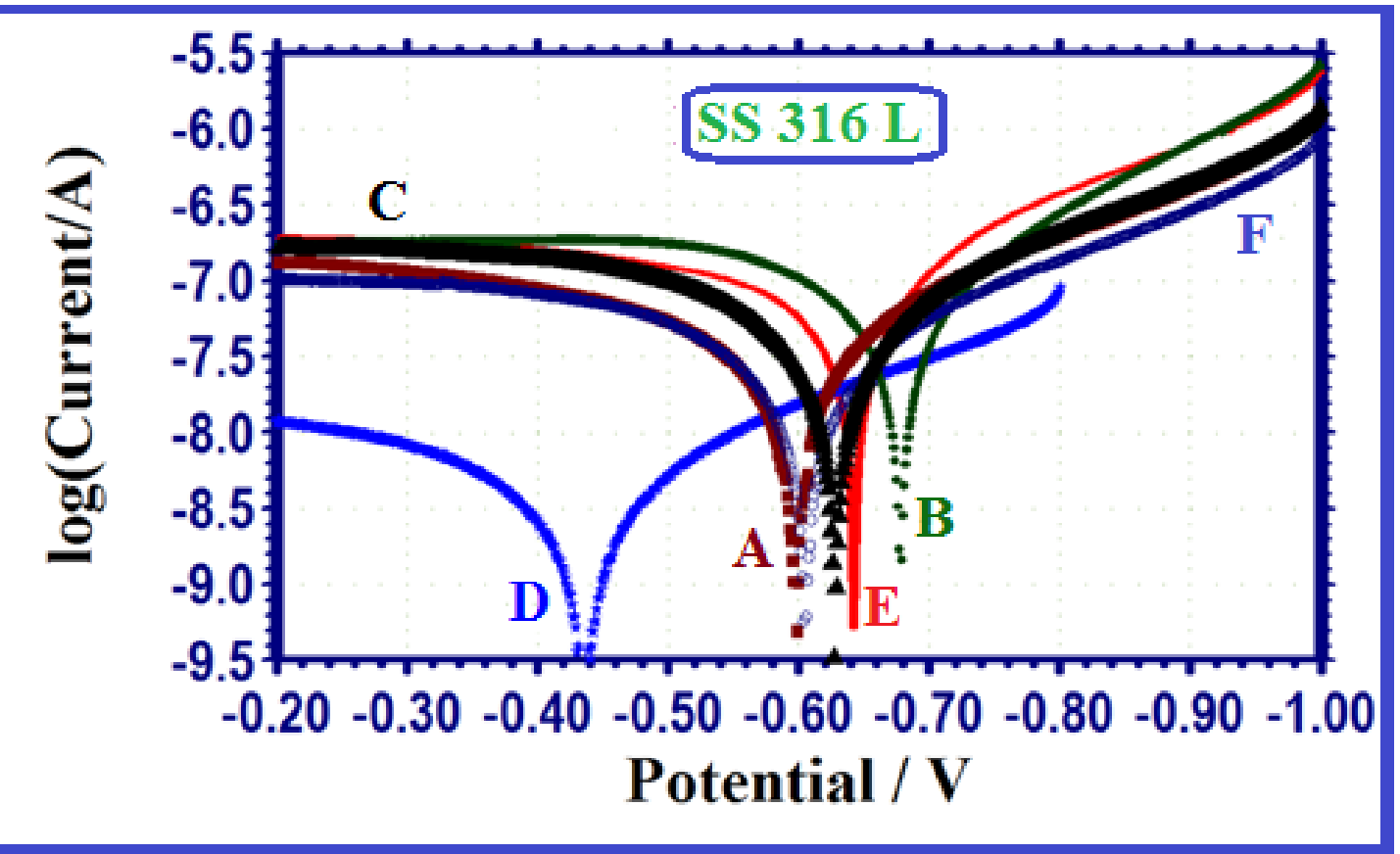

Figure 2. Polarisation curves of SS 316L alloy immersed in Artificial Saliva (AS) in the absence and presence of five tablets (potential vs SCE). 


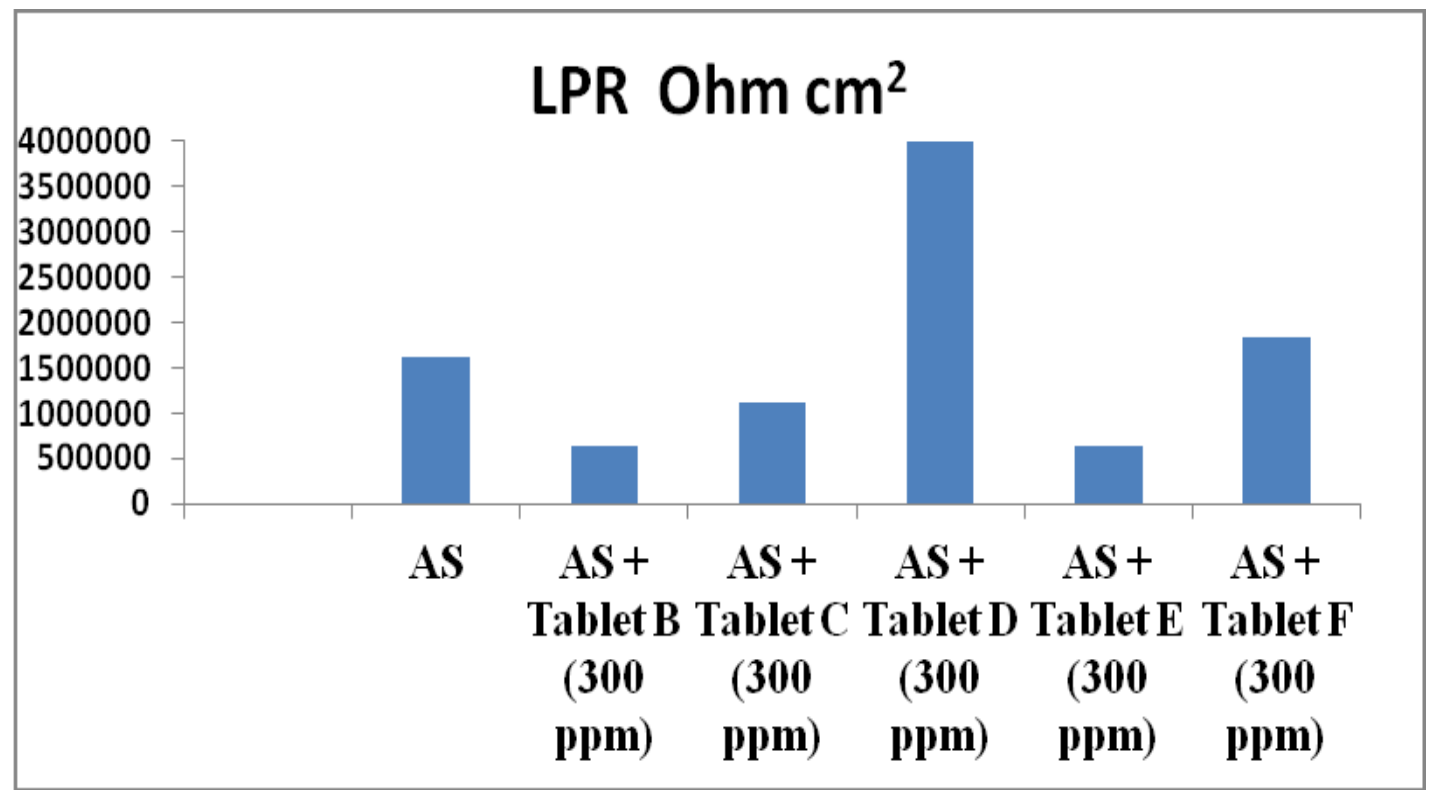

Figure 3. Corrosion resistance of SS 316L alloy immersed in Artificial Saliva (AS) in the absence and presence of five tablets.

The influence of Tablets $B, C$, and $E$ on SS $316 L$ alloy

It is observed from the Table 2 and Figure 3 that when SS 316L alloy is immersed in artificial saliva in the presence of Tablets B, C and E the LPR value decreases and the corrosion current increases (when compared with that in artificial saliva only). The active ingredients of the tablets have corroded the orthodontic wire made of SS 316L alloy. It implies that people having orthodontic wires made of SS 316L alloy should avoid taking these tablets orally.

\section{The influence of Tablets D and F on SS $316 L$ alloy}

It is observed from the Table 2 that in the presence of Tablets D and F the LPR values increase and corrosion current decreases. Hence it is concluded that in the presence of these tablets the corrosion resistance of SS 316L alloy increases. This may be due to the fact that in the presence of these tablets a protective layer is formed on the metal surface. These protective layers probably consist of complexes formed between the active principle of the ingredients of the tablets and metal ion present on the metal surface. The protective layer is compact and stable under the experimental condition. It implies that people having orthodontic wire made of SS 316L alloy need not hesitate to take Tablets D and F orally.

It is observed from the Table 2 that in the case of Tablet $\mathrm{B}, \mathrm{C}$ and $\mathrm{E}$ the corrosion potential is shifted to the cathodic side. This indicates that in the presence of these tablets cathodic reaction is controlled predominantly. In the case of Tablet D corrosion potential shifted to the anodic side. That is anodic reaction is controlled to a greater extent. In the case of Tablet F, the shift in corrosion potential is not very high. This means that the anodic reaction and cathodic reaction are controlled to an equal extent. The variation in 
corrosion potential is due to the presence of various active principles of the ingredients present in the tablets.

\section{Analysis of AC impedance spectra}

The AC impedance spectra of SS 316L alloy immersed in Artificial Saliva (AS) in the absence and presence of five tablets obtained from AC impedance spectra are shown in Figures 4,5 . The $\mathrm{AC}$ impedance parameters namely charge transfer resistance $\left(R_{\mathrm{t}}\right)$ and double layer capacitance $\left(C_{\mathrm{dl}}\right)$ derived from Nyquist plots (Figure 4) and Bode plots (Figure 5) are also given in this Table 3 [17-21]. In the Nyquist plot the extreme point in the high frequency region corresponds to $R_{\mathrm{s}}$ (solution resistance). The other extreme point in the low frequency region corresponds to $R_{\mathrm{s}}+R_{\mathrm{t}}$ (solution resistance + charge transfer resistance). Hence the difference between these two points gives the value of $R_{\mathrm{t}}$. Double layer capacitance was calculated from the relation $C_{\mathrm{dl}}=1 / 2 \times 3.14 \times R_{\mathrm{t}} \times f_{\max }$. From the Bode plot Impedance log $(z / \mathrm{Ohm})$ was noted.

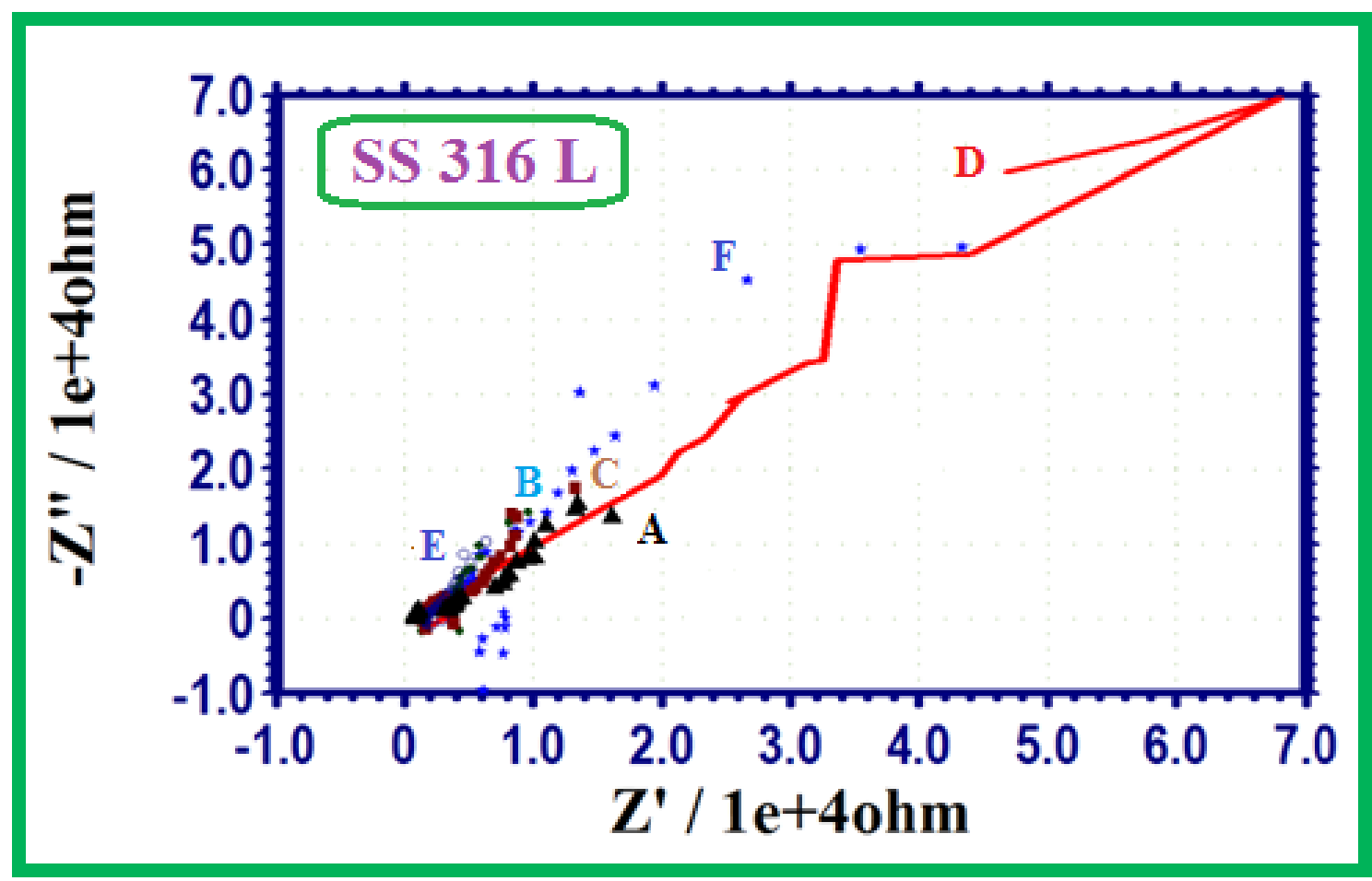

Figure 4. AC impedance spectra of SS 316L alloy immersed in Artificial Saliva (AS) in the absence and presence of five tablets (Nyquist Plots). 

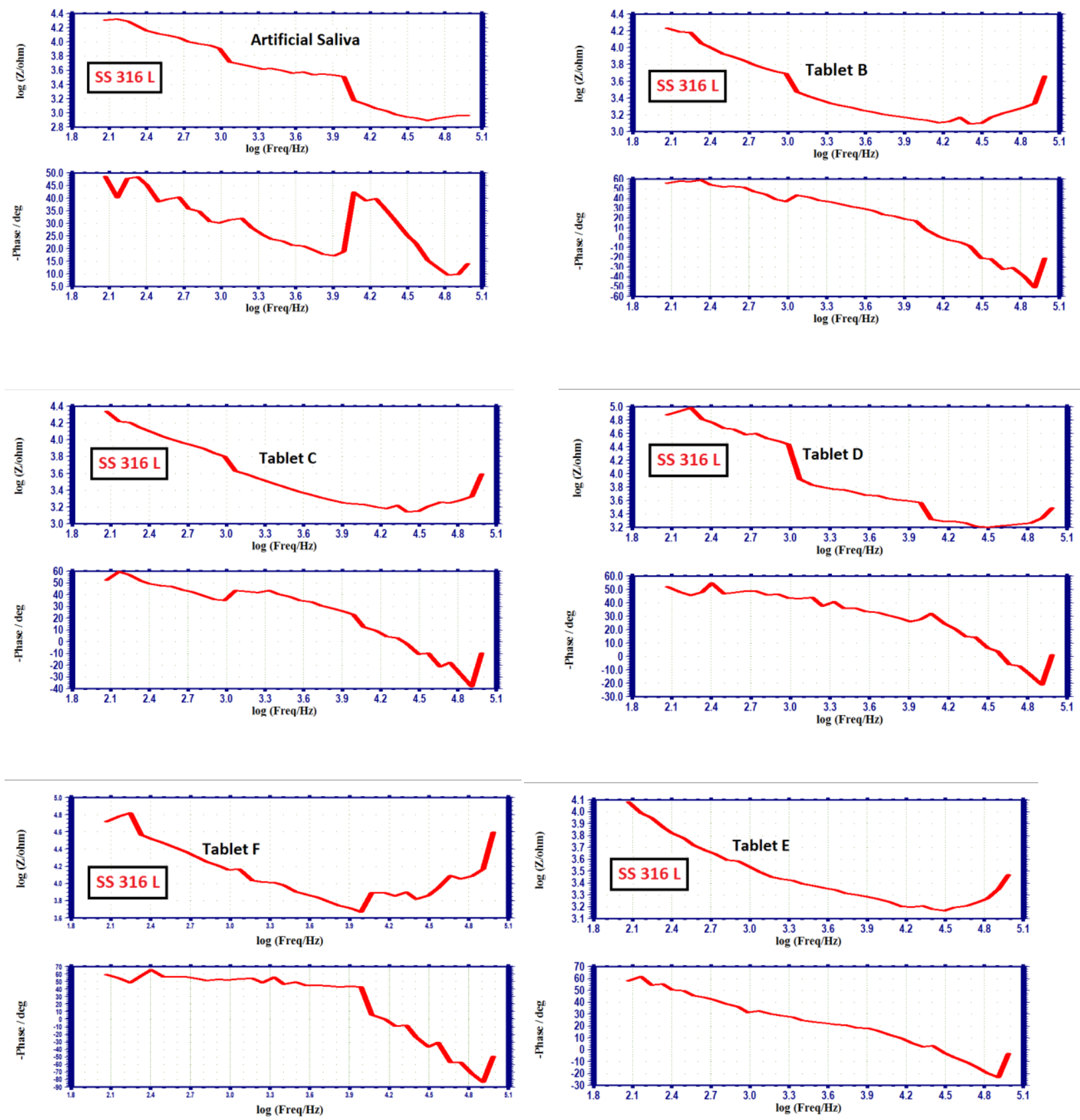

Figure 5. AC impedance spectra of SS 316L alloy immersed in Artificial Saliva (AS) in the absence and presence of five tablets (300 ppm) (Bode Plots). 
Table 3. AC impedance parameters of SS 316L alloy immersed in Artificial Saliva (AS) in the absence and presence of five tablets obtained by AC impedance spectra.

\begin{tabular}{|c|c|c|c|}
\hline System & $\begin{array}{c}R_{\mathrm{t}} \\
\text { Ohm } \mathbf{~ c m}^{2}\end{array}$ & $\underset{\mathbf{F} / \mathbf{c m}^{2}}{\mathbf{C}_{\mathrm{dll}}}$ & $\begin{array}{l}\text { Impedance } \\
\log (z / \mathrm{Ohm})\end{array}$ \\
\hline AS & 12412 & $4.109 \times 10^{-10}$ & 4.308 \\
\hline $\begin{array}{c}\text { AS + Tablet B } \\
(300 \mathrm{ppm})\end{array}$ & 5311 & $9.603 \times 10^{-10}$ & 4.234 \\
\hline $\begin{array}{c}\text { AS + Tablet } \mathrm{C} \\
(300 \mathrm{ppm})\end{array}$ & 9571 & $5.329 \times 10^{-10}$ & 4.301 \\
\hline $\begin{array}{c}\text { AS + Tablet D } \\
(300 \mathrm{ppm})\end{array}$ & 65030 & $0.7843 \times 10^{-10}$ & 4.874 \\
\hline $\begin{array}{c}\text { AS + Tablet E } \\
(300 \mathrm{ppm})\end{array}$ & 3377 & $15.102 \times 10^{-10}$ & 4.082 \\
\hline $\begin{array}{c}\text { AS + Tablet F } \\
(300 \mathrm{ppm})\end{array}$ & 17430 & $2.925 \times 10^{-10}$ & 4.725 \\
\hline
\end{tabular}

The equivalent circuit diagram is shown in Scheme 1. This results by considering a cell where semi-infinite diffusion is the rate determining step, with a series solution resistance as the only other cell impedance.

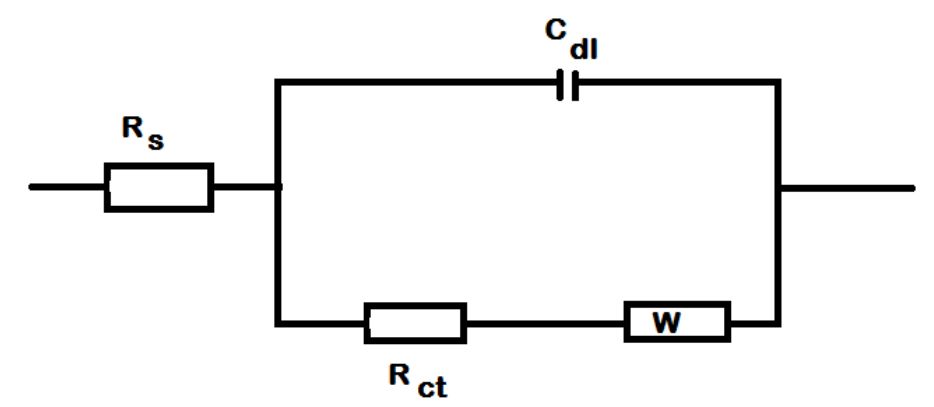

Equivalent Circuit with Mixed Kinetic and Charge-Transfer Control

$\mathbf{c}_{\mathbf{d l}}=$ Double layer Capacitance

$\mathbf{R}_{\mathbf{s}}=$ Solution Resistance

$\mathbf{R}_{\mathbf{c t}}=$ Charge Transfer Resistance

W = Warburg Impedance

Scheme 1. Equivalent Circuit diagram. 
The influence of Tablets $-B, C$, and E on SS $316 L$ alloy

In general when the charge transfer resistance $\left(R_{\mathrm{t}}\right)$ increases and double layer capacitance value $\left(C_{\mathrm{dl}}\right)$ decreases, Impedance value increases. It is observed from the Table 3 that when SS 316L alloy is immersed in artificial saliva the charge transfer resistance $\left(R_{\mathrm{t}}\right)$ decreases and the double layer capacitance value $\left(C_{\mathrm{dl}}\right)$ increases, Impedance value decreases.

When Tablets $\mathrm{B}, \mathrm{C}$ and $\mathrm{E}$ are introduced in to the artificial saliva, the corrosion resistance of SS $316 \mathrm{~L}$ alloy in contact with artificial saliva decreases. Hence AC impedance spectra lead to the conclusion that people having orthodontic wire made of SS $316 \mathrm{~L}$ alloy should not to take Tablet B, C and E. It is implies that people having orthodontic wire made of SS 316L alloy should avoid taking these tablets orally.

The influence of Tablets $D$ and F on corrosion resistance of SS $316 \mathrm{~L}$ alloy

It is observed from table 3 that in the presence of Tablet $\mathrm{D}$ and $\mathrm{F}$ the charge transfer resistance $\left(R_{\mathrm{t}}\right)$ increases, double layer capacitance value $\left(C_{\mathrm{dl}}\right)$ decreases and Impedance value increases. Hence it is confirmed that in the presence of these tablets the corrosion resistance of SS 316L alloy increases. It implies that people having orthodontic wire made of SS 316L alloy need not hesitate to take Tablets D and F orally.

\section{Conclusion}

Results of the electrochemical studies lead to the conclusion that in the presence of Tablet D and Tablet F, the corrosion resistance of SS 316L alloy in contact with artificial saliva increases. But in the presence of Tablets $\mathrm{B}, \mathrm{C}$ and $\mathrm{E}$ the corrosion resistance of SS 316L alloy in contact with artificial saliva decreases. Hence it is concluded that people implanted with the orthodontic wire made of SS 316 alloy can take the Tablet F orally without any hesitation but should avoid Tablets B, C and E.

\section{References}

1. A.C. Vieira, A.R. Ribeiro, L.A. Rocha and J.P. Celis, Wear, 2006, 261, 994.

2. D. Mareci, Gh. Nemtoi, N. Aelenei, and C. Bocanu, Eur. Cells Mater., 2005, 10, 1.

3. L. Kinani and A. Chtaini, Leonardo J. Sci., 2007, 11, 3340.

4. A. Ziebowicz, W. Walke, A. Barucha-Kepka and M. Kiel, J. Achiev. Mater. Manuf. Eng., 2008, 27, 151.

5. Ch. Liu, K.P. Chu, G. Lin and D. Yang, Corros. Sci., 2007, 49, 3783.

6. L. Joska, M. Marek and J. Leitner, Biomaterials, 2005, 26, 1605.

7. M.A.C. Brett and F. Trandafir, J. Electroanal. Chem., 2004, 52, 347.

8. M.A.C. Brett, I. Ioanitescu and F. Trandafir, Corros. Sci., 2004, 46, 2803.

9. V. Raman, S. Tamilselvi, S. Nanjundan and N. Rajendran, Trends Biomater. Artif. Organs, 2005, 18, 137.

10. S. Rajendran, J. Paulraj, P. Rengan, J. Jeyasundari and M. Manivannan, J. Dent. Oral Hyg., 2009, 1, 1. 
11. S. Rajendran, V. Uma, A. Krishnaveni, J. Jeyasundari, B. Shyamaladevi and M. Manivannan, Arabian J. Sci. Eng., 2009, 34, 47.

12. S. Rajendran, P.C. Devi, S.J. Mary, A. Krishnaveni, S. Kanchana, R. Nagalakshmi and B. Narayanasamy, Zastita Materijala, 2010, 51, 149.

13. R. Nagalakshmi, L. Nagarajan, R.J. Rathish, S.S. Prabha, N. Vijaya, J. Jeyasundari and S. Rajendran, Int. J. Nano. Corr. Sci. Engg., 2014, 1, 39.

14. J.A. Thangakani, S. Rajendran, J. Sathiabama, R.M. Joany, R.J. Rathis and S.S. Prabha, Int. J. Nano. Corr. Sci. Engg. 2014, 1, 50.

15. A. Nithya, P. Shanthy, N. Vijaya, R.J. Rathish, S.S. Prabha, R.M. Joany and S. Rajendran, Int. J. Nano Corr. Sci. Engg., 2015, $2,1$.

16. A.C.C. Mary, S. Rajendran, H. Al-Hashem, R.J. Rathish, T. Umasankareswari and J. Jeyasundari, Int. J. Nano Corr. Sci. Engg., 2015, 1, 42.

17. C.O. Akalezi, C.E. Ogukwe, E.A. Ejele and E.E. Oguzie, Int. J. Corros. Scale Inhib., 2016, 5, no. 2, 132. doi: $10.17675 / 2305-6894-2016-5-2-3$

18. T.A. Onat, D. Yiğit, H. Nazır, M. Güllü and G. Dönmez, Int. J. Corros. Scale Inhib., 2016, 5, no. 3, 273. doi: $10.17675 / 2305-6894-2016-5-3-7$

19. A.S. Fouda, M.A. El-Morsy, A.A. El-Barbary and L.E. Lamloum, Int. J. Corros. Scale Inhib., 2016, 5, no. 2, 112. doi: 10.17675/2305-6894-2016-5-2-2

20. V.I. Vigdorovich, L.E. Tsygankova, E.D. Tanygina, A.Yu. Tanygin and N.V. Shel, Int. J. Corros. Scale Inhib., 2016, 5, no. 1, 59. doi: 10.17675/2305-6894-2016-5-1-5

21. P.N. Devi, J. Sathiyabama and S. Rajendran, Int. J. Corros. Scale Inhib., 2017, 6, no. 1, 18. doi: $\underline{10.17675 / 2305-6894-2017-6-1-2}$ 